\title{
Retailing of Self-help Group (SHG) Products in India
}

\author{
Siddhartha Thyagarajan \\ Pondicherry University \\ T. Nambirajan \\ Pondicherry University \\ Ganeshkumar Chandirasekaran ${ }^{1}$ \\ Indian Institute of Plantation Management
}

The purpose of the study is retailing characteristics and problems of Self Help Groups (SHGs) Product in the Union Territory of Puducherry region. The research variables were identified from the literature review relating to retailing of SHG and primary data of 251 random sample of SHGs was collected through survey method using well-structured questionnaire. The statistical package of SPSS was utilized to analyze the data using the statistical techniques of descriptive statistics, Analysis of Variance test and Friedman test. Results shows that effectives of exclusive retail outlets for SHG products has been ranked first with a mean value of 4.43 indicating that for the retailing to be successful, there needs to be exclusive outlets for SHG products and the study will be a useful guide for making strategic decisions for the development of SHGs.

Keywords: Retailing, Problems, Self-Help Group, Product

\section{INTRODUCTION}

Self Help Groups (SHG) are small, homogenous, affinity groups from the poorer sections of society who, have voluntarily come together to save small amounts regularly which is deposited in a common fund to meet the members emergency needs and to obtain collateral free loans as decided by the group (Adams (2009)). The SHG is an informal group of persons numbering between 10 and 20 people from the economically poorer section of the society. SHG can also be described as a formal group of persons, which has been created for the purpose of collective support towards the process of empowerment and financial independence(Basargekar 2008). The SHG formation and group activity and has been evolved due to the various prevalent social conditions in society which may be dependency of women, large family size, low literacy rate, lack of funds, and lack of technical skills by vast sections of society(Ahluwalia, Carter, and Chenery 1979). The guiding principle of SHG formation and functioning is mutual trust and mutual support where individuals are equal and made responsible for actions while the group development is the primary motive of functioning and all decisions are made through consensus. Many definitions have been made of the SHG. As per Shanmugam (1991) A women's SHG is a small 
economically homogenous affinity group of rural poor women, voluntarily coming together to save a small amount of money regularly, to agree to contribute to a common cause, to meet emergent needs on a mutual help basis, to practice collective decision making, to solve conflicts through leadership and to provide collateral free loans with terms and conditions decided by the group (Copestake 2007)

Microfinance involves the provision of financial services such as savings, loans and insurance to poor people living in both urban and rural settings who are unable to obtain these services through from the formal financial sector. Microfinance has been defined by several persons on different ways. Microfinance is the provision of financial services to low-income poor and very poor self-employed people Otero (1999). Microfinance is the attempt to improve access to small deposits and small loans for poor households neglected by banks Schreiner and Colombet (2001). Microfinance refers to small-scale financial services for both credits and deposits, that are provided to people who farm or fish or herd; operate small or micro-enter [rises where goods are produced, recycled, repaired, or traded; provide services; work for wages, or commissions; gain income from renting out small amounts of land, vehicles, draft animals or machinery and tools; and to other individuals and local groups in developing countries in both rural and urban areas. "(Robinson 2001) Further to the above definitions of microfinance, microfinance can be described as the supply of basic financial services to the poor and low-income households where it aims to assist the marginalized groups of borrowers whom the formal credit institutions have found non-credit worthy and includes, the farm workers, urban poor, unemployed women and other poor mainly to reduce the levels of poverty in those segments by means of economic development (Sengottuvel \& Ganeshkumar, 2018).

To cater to such specific needs of the poor, microfinance institutions have developed providing exclusively microfinance services and through these institutions are smaller in scale than the traditional banking institutions they do fill the gaps in credit delivery to the many marginalized groups in society. Microfinance can comprise of several financial tools such as micro savings, microcredit, micro leasing, micro insurance and micro cash transfers(Janssens 2010). Micro savings can be described as accumulation of small amounts of money by individuals saved on a regular basis which can enable future consumption and its use during emergencies and which is deposited into accounts provided in banks. Micro remittances or micro cash transfers, refers to the small amounts of payments that the person receives from an employed person living elsewhere. Such micro remittances have the ability to create assets and facilitate the starting of microenterprise activities(Howells 1999). Microcredit refers to the provision of small loans to the poor households and their needs. It is characterized by standardized loan products, short periods, limited amounts, fixed repayment schedules and higher interest rates. Microcredit is today used through the system of group lending particularly through Self Help Groups (SHG). This method helps in the credit worthiness evaluation of group borrowers and this study will help to answer the research questions of the retailing characteristics and problems of Self Help Group (SHG) in Puducherry region(Heilman and Chen 2003).

\section{REVIEW OF LITERATURE}

Joy, Prema, and Krishnan (2008) have studied the determinants of group performance of women- led agro processing self-help groups in Kerala with objective of factors determining group performance using socioeconomic factors and group's performance variables and research found that variables such as age, education, market perception, motivation, risk orientation and innovativeness and training play a role in performance of the group(Tsai 2000). Ssewamala and Sherraden (2004) has examined integrating savings into micro enterprises through community based organizations promoting self-employment and found that integrating of savings, training and credit for microenterprises was found to be beneficial for the development of such enterprises and its owners(Tinker 2003). Madlani.M.B (2009) has explored women entrepreneurship and rural development with objective of concept, domain, rural marketing mix and

limitations of women entrepreneurs using sample data collection through questionnaire and found that the problems of women entrepreneurs is lack of facilities for training, marketing, and transportation in rural areas(Kanitkar 1994, Praharmayaki \& Rathinam, 2010). 
Swain and Wallentin (2009) has studied does micro finance empower women? Evidence from selfhelp groups in India with the objective of empowerment of women using Sample data collection through questionnaire for SHG bank linkage program from experimental and control groups and found that empowerment is lacking because of the excessive discriminatory systems. Empowerment comes through training, workshops and the inclusion in the decision making process(Sooryamoorthy 2007). Basargekar (2008) has studied economic empowerment through microfinance- An assessment of CSR Activity run by Forbes Marshall Ltd with objective to find out the impact of microfinance through interview technique of 217 SHG members and found that Interview technique of 217 SHG members(De Mel, McKenzie, and Woodruff 2009). Swain and Wallentin (2009) has explored does self-help-group participation lead to asset creation via data collection on previously enlisted members and new members of self-help groups and found that longer membership duration positively impacts asset creation. Training can lead to diversifying income streams and asset creation also in terms of livestock(Swain and Varghese 2009). Midgley (2008) has studied Inclusion of excluded with female empowerment through watershed management: A case study of self-help groups in Orissa through survey of SHG members in Ganjam district of Orissa and found that microcredit has the potential to eradicate poverty and generate employment. SHG can be made more successful by training, education and creating awareness programs(Kumar 2010).

(Monczka et al. (2015), Cull, Demirgüç-Kunt, and Morduch 2009) state in the study on microfinance banks that the microfinance banks have made significant contributions to society and have been able to improve the wealth of the nations. The authors also state that the banks that are associated with the financing of microenterprises are worth millions of dollars in stock since they are doing efficient business(Besley, Coate, and Loury 1993). The authors give the example of a bank Called Compartamos in Mexico which is doing profitable business in the area of microfinance and has been able to increase the client base from 60,000 customers in the year 2000 to 800,000 in the year 2007 and became the largest micro lender in Mexico in 2007(Geertz 1962). The authors state the Compartentos in Mexico was charging high interest rates but was able to obtain huge funds from the market as deposits due to its profitability in operations. They also are able to remove the money lenders who have been operating in this market with more stringent terms. The authors state that though microfinance was initially started for the agricultural borrowers, they have moved into other enterprises such as handicraft making, livestock farming and vending( Kumar \& Mohan, (2015), Kumar \& Mohan, (2015)). The banks argue that high interest is not important and the availability of finance to the needy is more important to the borrower and the banks argue there should be a win-win situation for both and hence poverty can be eradicated through profits. The banks also argue that subsidies provided by them are always short lived and will affect the profitability of the bank. The study notes that the many types of microfinance institutions fall under different categories such as NGO, Non-banking financial Institutions, Credit Unions and Rural banks. The author notes that the success of the non-profit institutions depends on the social investors such as world Banks' commercial lending arm International Finance Corporation(Midgley 2008, Ganeshkumar et al 2017). The author notes in findings that the profit margins at the top level microfinance institutions are attractive enough so as to attract the private funds. With the growth of technologies the reach and growth of microfinance will be greater than that being made now(Prahannayaki and Rathinam 2010).

\section{RESEARCH METHODOLOGY}

The purpose of the research work is to analyze and describe the retailing characteristics and problems of Self Help Groups. It can be hence understood that the research is descriptive in nature. First, Subject experts' options survey was conducted on the identified variable for questionnaire validity checking and required corrections were incorporated (Ganeshkumar and Nambirajan 2013, Ganeshkumar and Mohan 2014). The pilot survey of 30 SHGs was collected and initial Cronbach's- alpha value were estimated for checking the reliability of the questionnaire. Primary data for the main study was collected through the survey method of 251 random sample of SHGs were identified from the list of SHG maintained in the various banks, NGOs and Municipal bodies. The data was collected from the members and group leaders 
of SHGs by means of well-structured questionnaire. The statistical package of SPSS was utilized to analyze the data using the statistical tools descriptive statistics with frequency analysis and simple mean, Chi-square test and correspondence analysis (Hair, 2006).

\section{RESULTS AND DISCUSSION}

Data analysis and interpretation of the sample Self Help Groups (SHG) studied is portrayed in this section. Details such as number of persons with formal training, type of organization which provided training, amount willing to pay for training and priorities of training,

\section{Priorities of Retailing}

The retailing is an important aspect of entrepreneurship and it carries high significance among microenterprises. Retailing provides the means of sustenance for an SHG. When retailing aspects for a product are good then the production becomes sustainable wherein the microenterprises have the capacity to thrive. The opinions on the aspects of retailing in the form of mean values and their ranks are shown in the table below.

\section{TABLE 1}

\section{PRIORITIES OF RETAIL}

\begin{tabular}{|l|c|c|}
\hline \multicolumn{1}{|c|}{ Indicator } & Mean & Rank \\
\hline Effectiveness of exclusive retail point for SHG products & 4.43 & I \\
\hline Willingness in supply products in any retail brand name & 3.90 & II \\
\hline Easy to identify markets for sales & 3.04 & III \\
\hline Sales of products a big problem & 2.08 & IV \\
\hline Regularly we can produce and supply & 1.61 & V \\
\hline
\end{tabular}

From the above table it can be inferred that the effectives of exclusive retail outlets for SHG products has been ranked first with a mean value of 4.43 indicating that for the retailing to be successful, there needs to be exclusive outlets for SHG products. The second in rank is for the indicator on willingness to supply in any retail brand having a mean score of 3.90 showing a good preference of groups to supply products in any retail brands. Therefore the indicator ranked third with a mean rank of 3.04 pertains to easiness to identify markets which shows that finding markets is not so easy and requires assistance in doing so. The indicator which has been ranked last with a mean value of 1.61 is on regularity of supply which shows that the production cannot be very regular and is intermittent.

\section{ANOVA Test for Significant Difference between Numbers of Years of Functioning with Respect to Retail}

The ANOVA test to find the significant difference between demographic variable numbers of year functioning with respect to Retail is shown below. 
TABLE 2

ANOVA TEST RESULT FOR SIGNIFICANT DIFFERENCE BETWEEN NUMBER OF YEARS OF FUNCTIONING AND RETAIL

\begin{tabular}{|c|c|c|c|c|c|}
\hline \multirow{2}{*}{ Factor } & $\begin{array}{c}\text { Number of } \\
\text { Years }\end{array}$ & Mean & $\begin{array}{c}\text { Std. } \\
\text { Deviation }\end{array}$ & F Value & p Value \\
\hline \multirow{5}{*}{ Retail } & Below 1 & 16.4000 & 1.94936 & & \\
\cline { 2 - 4 } & $1-2$ & 15.5085 & 2.68696 & & \multirow{2}{*}{2.753} \\
\cline { 2 - 4 } & $2-3$ & 15.7647 & 2.74576 & \multirow{2}{*}{0.029} \\
\cline { 2 - 4 } & $3-4$ & 15.1842 & 2.20387 & \\
\cline { 2 - 4 } & Above 4 & 14.4375 & 2.61179 & & \\
\cline { 2 - 4 } & Total & 15.2908 & 2.64709 & & \\
\hline
\end{tabular}

Since $\mathrm{p}$ value is less than 0.05 the null hypothesis is rejected at 5 percent level of significance with regard to Retail. Hence concluded that there is significant difference between numbers of years of functioning with respect to Retail factor (Jamshi \& Ganeshkumar, 2017).

TABLE 3

DUNCAN MULTIPLE RANGE TEST RESULTS FOR RETAIL

\begin{tabular}{|c|c|c|c|}
\hline \multicolumn{4}{|c|}{ Retail } \\
\hline \multicolumn{4}{|l|}{ Duncan } \\
\hline \multirow{2}{*}{$\begin{array}{l}\text { Number of years } \\
\text { functioning of SHG }\end{array}$} & \multirow{2}{*}{$\mathrm{N}$} & \multicolumn{2}{|c|}{ Subset for alpha $=0.05$} \\
\hline & & 1 & 2 \\
\hline Above 4 & 64 & 14.44 & \\
\hline $3-4$ & 38 & 15.18 & 15.18 \\
\hline $1-2$ & 59 & 15.51 & 15.51 \\
\hline $2-3$ & 85 & 15.76 & 15.76 \\
\hline Below 1 & 5 & & 16.40 \\
\hline Sig. & & 0.162 & 0.202 \\
\hline \multicolumn{4}{|c|}{ Means for groups in homogeneous subsets are displayed. } \\
\hline
\end{tabular}

From Table 3, based on Duncan Multiple Range test, there is significant difference between above 4 years in operation with below 1 year in operation, but there is no significant difference between 3-4 years, 1-2 years and 2-3 years in operation with respect to retail activities.

ANOVA Test for Significant Difference between Numbers of Products Made with Respect to Retail

The ANOVA test to find the significant difference between demographic variable numbers of products with respect to Retail is shown below. 
TABLE 4

ANOVA TEST RESULT FOR SIGNIFICANT DIFFERENCE BETWEEN NUMBER OF PRODUCTS MADE AND RETAIL

\begin{tabular}{|c|c|c|c|c|c|}
\hline Factor & $\begin{array}{c}\text { Number of } \\
\text { products } \\
\text { made }\end{array}$ & Mean & $\begin{array}{c}\text { Std. } \\
\text { Deviation }\end{array}$ & F value & $P$ value \\
\hline \multirow{7}{*}{ Retailing } & No Products & 15.88 & 2.295 & \multirow{7}{*}{2.610} & \multirow{7}{*}{0.025} \\
\hline & One & 15.48 & 2.648 & & \\
\hline & Two & 15.70 & 2.488 & & \\
\hline & Three & 15.64 & 2.797 & & \\
\hline & Four & 14.77 & 2.365 & & \\
\hline & Above four & 14.03 & 2.844 & & \\
\hline & Total & 15.29 & 2.647 & & \\
\hline
\end{tabular}

From the above table it can be interpreted that since $\mathrm{p}$ value is less than 0.05 the null hypothesis is rejected at 5 percent level of significance with regard to retailing. Hence concluded that there is significant difference between number of products made and retailing.

TABLE 5

DUNCAN MULTIPLE RANGE TEST RESULTS FOR RETAILING

\begin{tabular}{|l|r|r|r|}
\hline \multicolumn{4}{|c|}{ Retail } \\
\hline Duncan & & \multicolumn{2}{|c|}{ Subset for alpha = 0.05 } \\
\cline { 3 - 4 } $\begin{array}{l}\text { Number of Products } \\
\text { Made }\end{array}$ & $\mathrm{N}$ & 1 & 2 \\
\hline Above four & 35 & 14.03 & \\
\hline Four & 46 & 14.77 & 14.77 \\
\hline One & 45 & 15.48 & 15.48 \\
\hline Three & 82 & & 15.64 \\
\hline Two & 8 & & 15.70 \\
\hline No Products & & 0.062 & 15.88 \\
\hline Sig. & & & 0.186 \\
\hline Means for groups in homogeneous subsets are displayed. \\
\hline
\end{tabular}

Based on Duncan Multiple Range test, there is significant difference between above four products with three products, two products and no products. But there is no significant difference between four products and one product with respect to retail.

\section{Friedman Test for Significant Difference Between Mean Ranks for Important Problems with Retailing}

The problems that the groups faced with retailing has been obtained through ranking. The ranks indicating the preference order. The greatest problem being ranked one and the least problem being ranked nine. Retailing being an important issue with the groups in selling the products. The mean ranks 
have been calculated through the Friedman test indicating the overall rank of the groups. The table below presents the mean ranks of the various problems in retailing of products.

TABLE 6

FRIEDMAN TEST RESULT FOR SIGNIFICANT DIFFERENCE BETWEEN MEAN RANKS FOR IMPORTANT PROBLEMS WITH RETAILING

\begin{tabular}{|c|c|c|c|}
\hline Problems with Retailing & Mean Rank & $\begin{array}{c}\text { Chi-square } \\
\text { value }\end{array}$ & $\mathrm{P}$ value \\
\hline No regular demand for products & 4.92 & \multirow{9}{*}{470.686} & \multirow{9}{*}{$0.001 * *$} \\
\hline No specific place to retail & 2.64 & & \\
\hline Distance from markets & 3.72 & & \\
\hline Transportation problems & 3.73 & & \\
\hline Low quality of produce & 5.77 & & \\
\hline Low variety of products & 5.69 & & \\
\hline Higher cost of production & 6.04 & & \\
\hline No training in sales & 6.17 & & \\
\hline No awareness among public for SHG products & 6.31 & & \\
\hline
\end{tabular}

Note: $* *$ Denotes significant at $1 \%$ level

Since $\mathrm{p}$ value is less than 0.01 , the null hypothesis is rejected at 1 percent level of significance. Hence it is concluded that there is significant difference between mean ranks with regard to problems with retailing. Based on mean rank score, the most important problem has been ranked as no specific place to retail with a mean rank score of 2.64 , followed by distance from markets with a score of 3.72 , followed by transportation problem indicating a score of 3.73, followed by no regular demand for products with a score of 4.92. The remaining problems have been ranked as follows, low variety of products with score 5.69 , low quality of produce with score 5.77, higher cost of production with score 6.04 , no training in sales with score 6.17 and the last ranked being no awareness among public for SHG products with a score of 6.31 .

\section{Friedman Test for Significant Difference Between Mean Ranks for Ideal Mode of Distribution}

The choice of ideal mode of distribution has been obtained again through ranks indicating the indicating best option and worst options. The ranks being the order of preference. Distribution methods can be of many types and the preference of the groups is indicated to suit their individual conditions. The mean ranks have been calculated using the Friedman test. The table below presents the mean ranks of the ideal mode of distribution among the groups.

\section{TABLE 7 \\ FRIEDMAN TEST RESULT FOR SIGNIFICANT DIFFERENCE BETWEEN MEAN RANKS FOR THE IDEAL MODE OF DISTRIBUTION}

\begin{tabular}{|c|c|c|c|}
\hline $\begin{array}{l}\text { Ideal Mode Of Distribution } \\
\end{array}$ & Mean Rank & Chi-square value & P value \\
\hline Directly to Customers & 2.02 & \multirow{7}{*}{692.870} & \multirow{7}{*}{$0.001 * *$} \\
\hline Through retailers & 2.82 & & \\
\hline Through Distributors and wholesalers & 3.87 & & \\
\hline Through own retail outlet & 3.86 & & \\
\hline Government built markets & 4.42 & & \\
\hline SHG marketing centers & 4.32 & & \\
\hline Any other & 6.69 & & \\
\hline
\end{tabular}

Note: $* *$ Denotes significant at $1 \%$ level 
Since $\mathrm{p}$ value is less than 0.01 , the null hypothesis is rejected at 1 percent level of significance. Hence it is concluded that there is significant difference between mean ranks indicating ideal mode of distribution. Based on mean rank, providing directly to customers indicating a mean rank score of 2.02 is the ideal mode of distribution, followed by providing products through retailers indicating a score of 2.82, followed by selling through own retail outlet indicates a score of 3.86, which is followed by selling through distributors and wholesalers indicting a mean rank value of 3.87 and lastly through government built markets with a mean rank score of 4.42 .

\section{Friedman Test for Significant Difference Between Mean Ranks for Ideal Location of Retail Outlet}

Retail outlet locations can be at many places and the preference of the groups is suited to their products and existing conditions. The ideal location for a retail outlet for group products has been obtained through ranks indicating the best option and last option for location. The ranks being the order of preference. The ranks of preference have been calculated using the Friedman test indicating the overall mean ranks. The table below presents the mean ranks of the ideal location for retail outlets by the groups.

TABLE 8

\section{FRIEDMAN TEST RESULTS FOR SIGNIFICANT DIFFERENCE BETWEEN MEAN RANKS FOR IDEAL LOCATION FOR RETAIL OUTLETS}

\begin{tabular}{|c|c|c|c|}
\hline Ideal Location for Retail Outlet & Mean Rank & Chi-square Value & $P$ value \\
\hline Central part of town & 2.06 & \multirow{10}{*}{855.812} & \multirow{10}{*}{$0.001 * *$} \\
\hline Periphery of town & 5.90 & & \\
\hline Highways between towns & 4.75 & & \\
\hline Exhibition Centers & 4.86 & & \\
\hline Tourist Spots & 5.25 & & \\
\hline Beach & 5.75 & & \\
\hline Theme parks and recreation spots & 6.08 & & \\
\hline Bus stands & 5.43 & & \\
\hline Main Market place & 5.24 & & \\
\hline Others & 9.70 & & \\
\hline
\end{tabular}

Note: $* *$ Denotes significance at $1 \%$ level

Since $\mathrm{p}$ value is less than 0.01 , the null hypothesis is rejected at 1 percent level of significance. Hence it is concluded that there is significant difference between mean ranks towards ideal location for retail outlets. Based on mean ranks score, central part of town with a score of 2.06 is the first most preferred ideal location for retail outlet, followed by highways between towns as second most preferred location with a score of 4.75 , followed by exhibition centers as third most preferred location with a score of 4.86 , followed by main market place with a score of 5.24, followed by tourist spots with a score of 5.25 followed by bus stands with a score of 5.43 followed by beach with a score of 5.75 , followed by periphery of town with a score of 5.90, followed by theme parks and recreation spots with a score of 6.08 .

\section{CONCLUSIONS AND IMPLICATIONS}

Research results shows that effectives of exclusive retail outlets for SHG products has been ranked first with a mean value of 4.43 indicating that for the retailing to be successful, there needs to be exclusive outlets for SHG products. The second in rank is for the indicator on willingness to supply in any retail brand having a mean score of 3.90 showing a good preference of groups to supply products in any retail brands. ANOVA result depicts that there is significant difference between numbers of years of 
functioning with respect to Retail factor and there is significant difference between number of products made and retailing (Siddhartha et al, 2017, Thyagarajan et al, 2018a\&b).

Friedman Test result shows that there is significant difference between mean ranks with regard to problems with retailing. Based on mean rank score, the most important problem has been ranked as no specific place to retail with a mean rank score of 2.64, followed by distance from markets with a score of 3.72 , there is significant difference between mean ranks indicating ideal mode of distribution. Based on mean rank, providing directly to customers indicating a mean rank score of 2.02 is the ideal mode of distribution, followed by providing products through retailers indicating a score of 2.82 , followed by selling through own retail outlet indicates a score of 3.86, which is followed by selling through distributors and wholesalers indicting a mean rank value of 3.87 and lastly through government built markets with a mean rank score of 4.42 and There is significant difference between mean ranks towards ideal location for retail outlets. Based on mean ranks score, central part of town with a score of 2.06 is the first most preferred ideal location for retail outlet, followed by highways between towns as second most preferred location with a score of 4.75 , followed by exhibition centers as third most preferred location with a score of 4.86 , followed by main market place with a score of 5.24 , followed by tourist spots with a score of 5.25. The research study endeavors to study the various distribution activities performed by the SHG in the Union Territory of Puducherry Region. The study will be a useful guide for making strategic decisions for the development of SHGs. Thus this research will be of immense utility to the Government, Banks, Microfinance Organizations and other policy makers.

\section{ENDNOTE}

1. Corresponding Author

\section{REFERENCES}

Adams, D. (2009). Easing poverty through thrift. Savings and Development, 33(1), 73-85.

Ahluwalia, M. S., Carter, N. G., \& Chenery, H. B. (1979). Growth and poverty in developing countries. Journal of development economics, 6(3), 299-341.

Basargekar, P. (2008). Economic Empowerment Through Microfinance: An Assessment of CSR Activity run by Forbes Marshall Ltd. International Journal of Business Insights \& Transformation, 2(1).

Besley, T., Coate, S., \& Loury, G. (1993). The economics of rotating savings and credit associations. The American Economic Review, 792-810.

Copestake, J. (2007). Mainstreaming microfinance: social performance management or mission drift?. World development, 35(10), 1721-1738.

Cull, R., Asli Demirgüç-Kunt, A., \& Morduch, J. (2009). Microfinance meets the market. Journal of Economic perspectives, 23(1), 167-92.

De Mel, S., McKenzie, D., \& Woodruff, C. (2009). Are women more credit constrained? Experimental evidence on gender and microenterprise returns. American Economic Journal: Applied Economics, 1(3), 1-32.

Ganeshkumar, C., \& Mathan Mohan, G. (2014). Data Assumptions Checking for Estimating Structural Equation Modeling: Supply Chain Context. Anvesha, 7(4).

Ganesh Kumar, C., Murugaiyan, P., \& Madanmohan, G. (2017). Agri-food Supply Chain Management: Literature Review.

Ganeshkumar, C., \& Nambirajan, T. (2013). Supply chain management components, competitiveness and organisational performance: causal study of manufacturing firms. Asia-Pacific Journal of Management Research and Innovation, 9(4), 399-412.

Geertz, C. (1962). The rotating credit association: A"middle rung" in development. Economic development and cultural change, 10(3), 241-263.

Hair, J. F. (2006). Multivariate data analysis. Pearson Education India. 
Heilman, M. E., \& Chen, J. J. (2003). Entrepreneurship as a solution: the allure of self-employment for women and minorities. Human Resource Management Review, 13(2), 347-364.

Howells, L. A. (1999). The dimensions of microenterprise: A critical look at microenterprise as a tool to alleviate poverty. J. Affordable Hous. \& Cmty. Dev. L., 9, 161.

Jamshi, J., \& Ganeshkumar, C. (2017). Causal Linkage among Business Analytics, Supply Chain Performance, Firm Performance and Competitive Advantage. Parikalpana, 29.

Janssens, W. (2010). Women's empowerment and the creation of social capital in Indian villages. World Development, 38(7), 974-988.

Joy, L., Prema, A., \& Krishnan, S. (2008). Determinants of group performance of women-led agroprocessing self-help groups in Kerala. Agricultural Economics Research Review, 21(347-201616676), 355.

Kumar, C. G., \& Mohan, G. M. (2015). Sustainable Performance Of Indian Manufacturing Firms. Global Management Review, 9(2).

Kumar, C. G., \& Nambirajan, T. (2013). Supply chain management concerns in manufacturing industries. IUP Journal of Supply Chain Management, 10(4), 69.

Kanitkar, A. (1994). Entrepreneurs and micro-enterprises in rural India. Economic and Political Weekly, M25-M30.

Kumar, S. (2010). SHG-Linked microcredit in Kerala-A Micro-scan of prospects and problems of Kudumbashree linked Microenterprises. Macro Dynamics of Microfinance, 1(1), 335-342.

Madlani, M. B. (2013). Women entrepreneurship and rural development. Commerce and Management, 2(12), 94-98.

Midgley, J. (2008). Microenterprise, global poverty and social development. International Social Work, 51(4), 467-479.

Monczka, R. M., Handfield, R. B., Giunipero, L. C., \& Patterson, J. L. (2015). Purchasing and supply chain management. Cengage Learning.

Otero, M. (1999). Bringing development back, into microfinance. Journal of Microfinance/ESR Review, 1(1), 2.

Praharmayaki, J., \& Rathinam, M. (2010). Micro Credit: A unique process of Socioeconomic Engineering. Macro Dynamics of Micro Finance, PP-163-175.

Robinson, M. S. (2001). The microfinance revolution: Sustainable finance for the poor. The World Bank.

Schreiner, M., \& Colombet, H. H. (2001). From urban to rural: Lessons for microfinance from Argentina. Development policy review, 19(3), 339-354.

Sengottuvel, E. P., \& Ganeshkumar, C. (2018). The Impact of Economic Policy on Institutional Credit Flow to Agricultural Sector. IUP Journal of Applied Economics, 17(2), 80-97.

Shanmugam, B. (1991). Socio-economic development through the informal credit market. Modern Asian Studies, 25(2), 209-225.

Siddhartha, T., Nambirajan, T., \& Ganeshkumar, C. (2017). Distribution Methods Adopted for Self-Help Group Products: An Empirical Analysis. IUP Journal of Operations Management, 16(4), 25-33.

Sooryamoorthy, R. (2007). Microcredit for microenterprises or for immediate consumption needs?. Sociological Bulletin, 56(3), 145-157.

Ssewamala, F. M., \& Sherraden, M. (2004). Integrating saving into microenterprise programs for the poor: Do institutions matter?. Social Service Review, 78(3), 404-429.

Swain, R. B., \& Varghese, A. (2009). Does self help group participation lead to asset creation?. World Development, 37(10), 1674-1682.

Swain, R. B., \& Wallentin, F. Y. (2009). Does microfinance empower women? Evidence from self-help groups in India. International review of applied economics, 23(5), 541-556.

Tinker, I. (2003). Street foods: Traditional microenterprise in a modernizing world. International Journal of Politics, Culture, and Society, 16(3), 331-349.

Thyagarajan, S., Nambirajan, T., \& Chandirasekaran, G. (2018a). Help Financial Operations and Product Preferences of Self Help Groups (SHG). SJCC Management Research Review, 8(1), 20-32. 
Thyagarajan, S., Thangasamy, N., \& Chandirasekaran, G. (2018b). Legal Requirements for Linking SelfHelp Groups to Micro, Small and Medium Enterprises. IUP Law Review, 8(2).

Tsai, K. S. (2000). Banquet banking: Gender and rotating savings and credit associations in South China. The China Quarterly, 161, 142-170. 